Research Article

\title{
Determination of Equilibrium Moisture Content in Trade Distribution
}

\author{
David S S Marpaung ${ }^{*}$, Anggia Indryani², Ayu Oshin Yap Sinaga ${ }^{3}$ \\ ${ }^{1}$ Department of Biosystems Engineering, Institut Teknologi Sumatera (ITERA), Lampung Selatan, \\ Indonesia \\ 2 Department of Agriculture Engineering, Universitas Lampung, Bandar Lampung, Indonesia \\ ${ }^{3}$ Department of Biology, Institut Teknologi Sumatera (ITERA), Lampung Selatan, Indonesia
}

Article history:

Submission January 2020

Revised May 2020

Accepted June 2020

${ }^{*}$ Corresponding author:

E-mail:

david.marpaung@tbs.itera.ac.id

\begin{abstract}
Maize is one of essential crop in Indonesia. Maize trade distribution showed economic condition in society. If the distribution trade was poor, the quality and quantity of product will be low, consequences to uncontrolled condition in society. Every actor in distribution trade play important role. Farmer for instance, if the farmer produces low quality of maize grain, will resulted unacceptable product in factory. The acceptance of maize in feed factory is determined by several factor, such as moisture content, microorganism contamination, and presence of pest. To know the best recommendation treatment to prevent rejected product in feed factory, it is important to determine the moisture content in trade distribution, because the higher moisture content would increases the possibility of microorganism contamination. Besides, the best condition storage is also critical for keeping the quality of maize grain. Therefore, determination of equilibrium moisture content (EMC) will help the policies maker to consider environment condition for their storage. In this study, the maize EMC was determined using Henderson's equation. The results showed that the highest EMC was found in the maize after threshing $(23.49 \pm 0.58 \%)$. The postharvest treatment, such as drying and sortation is very important apply in such point
\end{abstract}

Keywords: Maize, moisture content, trade distribution

\section{Introduction}

Maize is one of potential crop in Indonesia. Maize commonly used as a source of energy, either through food or feed. As a food, many diversification products using maize a rawmaterial, such as ice, chips (Hasanah\&Dessy, 2019), cake, drinking products (Alsuhendra\&Ridawati, 2017) and many other products unpublished in scientific article. Besides, maize is also able used as sources of energy, such as bioenergy, bio-renewable materials and biofuels (Thiex\&Richardson, 2004; BPS, 2015) In Lampung Province, the productivity of maize is growing up year by year, from 1993 to 2015 (BPS, 2015). Moreover, in 2016 the production value of maize in Lampung reach 1.72 million tonnes, contributed for 7.29\% of total national production (Bappeda, 2017). It means that Lampung Province put concern in maize production improvement. Therefore, development of maize production is important, both in quantity and quality aspect.

Distribution pattern in trade represent the distribution chain from producer to consumer. The good distribution chain will able to move the product with very low cost and fairly control the cost to all of distribution chain actor (BPS, 2015). The availability of maize in market gives multiple effects to enterprises, especially livestock business area (Mango et al., 2018). It means quantity and quality of maize will affect the distribution chain, from producer to consumer.

Moisture content is one of the common problems in distribution chain, in terms of acceptability maize in factory. Each of feed factories has their own rule for maize moisture

How to cite:

Marpaung DSS, Indryani A, Sinaga AOY (2020) Determination of Equilibrium Moisture Content in Trade Distribution. Journal of Agriculture and Applied Biology 1 (1): 25 - 29. doi: 10.11594/jaab.01.01.04 
content from farmer or other actor in distribution chain. High moisture content in maize combine with high relative humidity are potentially become comfort growth condition for fungi (Sauer\&Tuite, 1987). Precise moisture content measurements are important for many reasons in the feed sector (Thiex\&Richardshon, 2004) Water is weight and must be charged to buy and sell food; 2) Water is weight and has to be shipped; 3) In storage conditions, moisture content plays a role; 4) Moisture in feedstuffs and mixed feeds works as a diluent to energy, protein, minerals, and methods for the evaluation of empirical methods; 5) Proper concentrations of moisture in diets are necessary for optimum intake and performance of animals. Therefore, a precise determination of moisture content along distribution chain is necessary for preventive handling.

The equilibrium moisture content (EMC) is essential properties in the analysis and design of various food processing. Proper environment condition will determined the quality of agriculture product (Widyasanti et al., 2017). The EMC data is necessary to consider the grain storage condition. However, most of maize enterprise ignores to evaluate the EMC data. (Zhang\&Mittal, 2013) found the EMC of several foods using artificial neural network. The aim of this study was to measure the EMC of maize along distribution chain using Henderson's equation.

\section{Material and Methods Sample Preparation}

This study was conducted in one of small enterprise in Lampung. This research was carried out through direct observation and field measurements. The distribution trade, including farmers and traders, was determined by direct observation.

\section{Sampling Methods}

The system of sampling was conducted in 3 different points with 3 replications in maize distribution trade, maize in field, maize after move from farm to thresher and maize that ready to send to factory. The sampling technique is based on the SNI 19-0428-1998 solid sampling method. The sample was collected from each point to quantify the moisture content.

\section{Moisture Content Measurement}

The measurement of maize moisture content was carried out using oven method (AOAC, 1995). The amount of sample 3-4 gram was put in oven $100-105^{\circ} \mathrm{C}$ for 6 hours and move to desiccator. The sample was dried until the weight constant. The moisture content was calculated based on weight losses, the difference between initial weight and latter weight of sample.

\section{Equilibrium Moisture Content (EMC)}

The EMC in trade distribution was quantified using henderson's equation [12]. The Henderson's Equation was calculated by the equation:

$$
1-R H=\exp \left[-c T(M e)^{n}\right]
$$

$$
\begin{array}{ll}
\text { Where } & \\
\text { RH } & : \text { Relative Humidity }(\%) \\
\text { c maize } & : 1.10 \times 10^{-5} \\
\text { n maize } & : 1.90 \\
\text { T } & : \text { Temperature }(\mathrm{K}) \\
\text { Me } & : \text { Equilibrium Moisture Content }
\end{array}
$$

\section{Results and Discussion \\ Field Condition}

The land owner for maize production is the local farmer with 2-2.75 Ha area of dry land. The frequency of maize cultivation reach2-3 times per year, depend on the weather condition. The maturity level was adjusted traditionally by observed the stalk and husk of maize. To reduce the moisture content level of maize, the farmer are usually using sun dryer for 1-3 days. However, determination of moisture content during sun drying is difficult, caused by broken maize kernel in overdried condition. Therefore, non-destructive detection of maize moisture content is recommended in farm level. There are several nondestructive detection methods could be applied at farm level, including using used ring electrode pair as sensors (Zhang et al., 2016), 555 integrated circuit timer (Klomklao et al., 
2017), microcontroller (Oktavianty\&Wildian, 2016) and web based capacitive (Savero et al., 2018). Preventive action could be controlled when the moisture content already known at farm level.

\section{Trader Condition}

The trader has important role to send the maize grain to feed industry. In $1 \mathrm{Ha}$, farmer normally produces 6 tonnes maize grain and send to trader. The maize normally just spread out on the floor in summer time, rely on the sun as source for drying. In order to reduce the moisture content of maize, indoor drying treatment is necessary. The proper packaging for maize after threshing is important. Risanda et al., found that combination of plastic bag and hermetic packaging was able to maintain material moisture content remains low. The main aim of the packaging is the elimination of losses in post-harvest processing (Marpaung et al., 2019). However, the packaging with nondegradable material, such as conventional plastic must be one of consideration for environment sustainability, including greenhouses gasses emission (Cahyani et al., 2019).

The three different points in maize distribution trade, maize in field, maize after move from farm to thresher and maize that ready to send to factory showed in Figure 1.

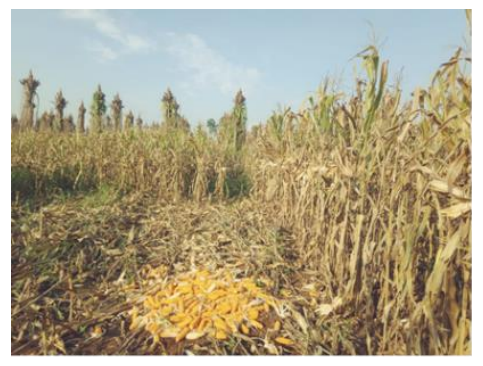

a)

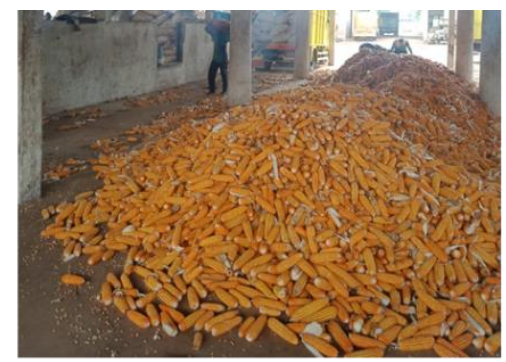

b)

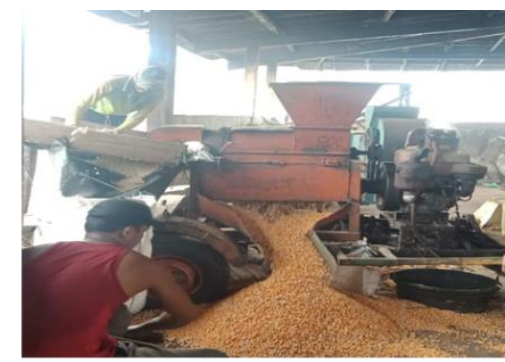

c)

Figure 1. a) Maize in field; b) Maize after move from farm to thresher; c)Maize that ready to send to factory

\section{Moisture Content Along Distribution Trade}

A precise evaluation is important for the moisture content of foodstuffs because the nutritional evaluation is affected by moisture content. The oven method drying was appropriate to determine of the moisture content of feed ingredients, which included maize (Ahn et al., 2014). The moisture content of maize in different point of distribution trade was showed in Fig 2. The highest moisture content $(20.47 \pm 1.67 \%)$ was found in the maize after move from farm. The moisture content increases from farm and decreases after threshing treatment. The increasing of moisture content in the trader is caused bythe absence of dried treatment. The maize that spread out on the floor outside to wait threshing treatment makes the moisture content going down. Such matter just happened during the summer time, due to the temperature and relative humidity in optimum condition. After the maize is threshed, the moisture content was decreased.

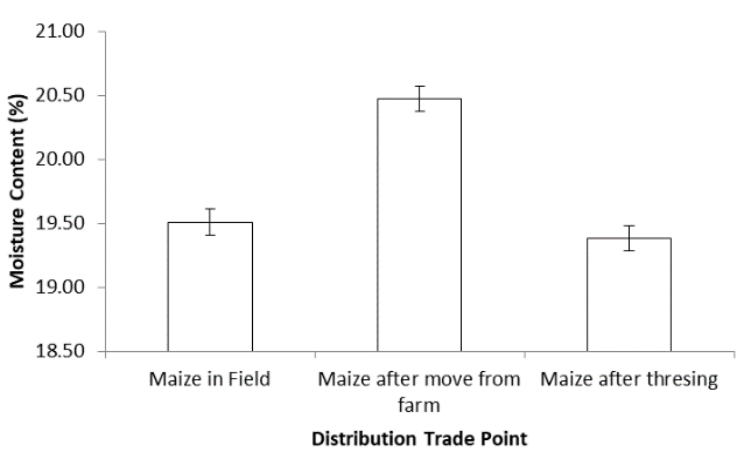

Figure 2. The moisture content of maize in different point of distribution trade (three times replicate)

The need for assessment and improvement of moisture methods and standardization of laboratory practices is very important.

\section{Environmental Condition}

Determination of environmental condition was conducted along distribution trade. 
The highest temperature $\left(33.1 \pm 0^{\circ}\right)$ was found in the field. Different result was found on relative humidity. The highest relative humidity $(74 \pm 1.73 \%)$ was found in the location maize after threshing. Determination of relative humidity and temperature in maize storage will help the trader to keep the quality and safety of raw materials for process controlling and food preservation (Butts-Wilmsmeyer et al., 2019; Palacious et al., 2019). Temperature and relative humidity are important factors in grain storage, due to its effect to EMC (Hanif et al., 2018).

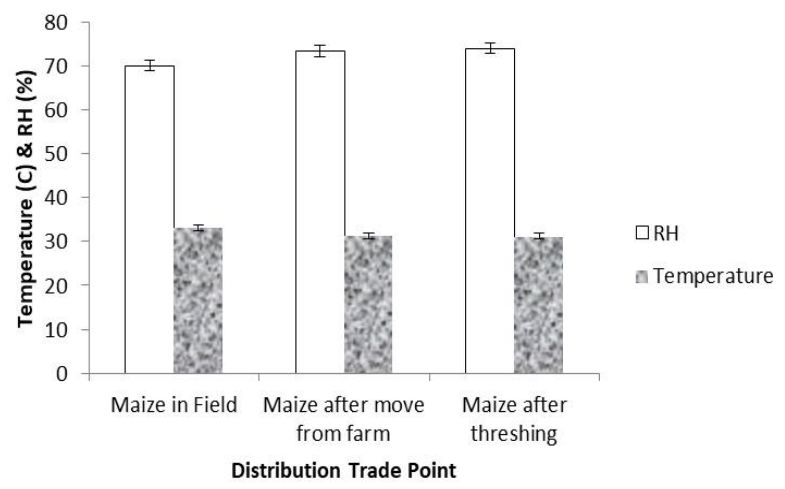

Figure 3. The Environmental Condition in different point of distribution trade (three times replicate)

\section{Equilibrium Moisture Content}

The function of temperature and relative humidity of drying air is defined asequilibrium moisture contents (EMC). It is important in order to develop control strategies for the safe storage of agricultural products. The highest EMC was found in the location maize after threshing $(23.49 \pm 0.58 \%)$. The finding of highest EMC after maize threshing because of its high temperature and RH. Different types of grains require different amount of moisture level for storage (Hanif et al., 2018).

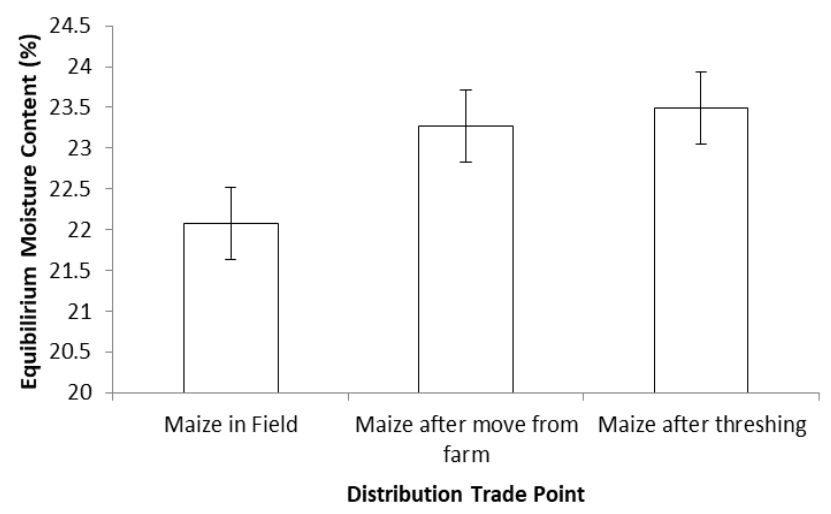

Figure 4. The Equilibrium Moisture Content in different point of distribution trade (three times replicate)

\section{Conclusion and Recommendation}

Determination of EMC is important for grain storage consideration. The best condition of EMC will effect on the moisture content of maize grain, consequences on product acceptability in feed factories. The highest EMC was found in the maize after threshing. Serious post-harvest handling, such as drying or sortation, is important reduce moisture content level before send to factories.

\section{Acknowledgment}

This work was funded by Ministries of Research, Technology and Higher Education of the Republic of Indonesia. Contract number: 009/SP2H/LT/DRPM/2019. 


\section{References}

Ahn, J., Kil, D., Kong, C., \& Kim, B. (2014). Comparison of Ovendrying Methods for Determination of Moisture Content in Feed Ingredients. Asian-Australasian journal of animal sciences, 27, 1615-1622.

Alsuhendra., \& Ridawati. (2017). Pelatihan Diversifikasi Produk Olahan Jagung Manis pada Tutor Pendidikan Anak Usia Dini di Kecamatan Makasar, Jakarta Timur. Agrokreatif 3, 100-107.

AOAC. (1995). Official methods of analysis of AOAC International, 16th edition. 1, (Arlington: AOAC International).

Bappeda. (2017). Report of Action Plan for Food and Nutrition Lampung Province.

BPS. (2015). Trade Distribution of Maize Grain Indonesia 2015.

Butts-Wilmsmeyer, C.J., Seebauer, J.R., Singleton, L., and Below, F. E. (2019). Weather during key growth stages explains grain quality and yield of maize. Agronomy, 9, 16.

Cahyani, D., Haryanto, A., Putra, G. A., Fil'aini, R., Marpaung, D. S. S. (2019). Life cycle assessment of biogas digester in small scale tapioca industry. IOP Conference Series: Earth and Environmental Science 258, 012017.

Hasanah, L., \&Dessy, I. (2019). Diversifikasi Pangan Olahan Jagung Manis Sebagai Upaya Pengembangan Agroindustri di Desa Soropaten. Jurnal Pengabdian Masyarakat JDINAMIKA, 4, 28-33.

Klomklao, P., Kuntinugunetanon, S., \& Wongkokua, W. (2017). Moisture content measurement in paddy. In Journal of Physics: Conference Series (IOP Publishing): pp. 012068.

Mango, N., Mapemba, L., Tchale, H., Makate, C., Dunjana, N., \& Lundy, M. (2018). Maize value chain analysis: A case of smallholder maize production and marketing in selected areas of Malawi and Mozambique. Cogent Business \& Management, 5, 1503220.

Marpaung, D. S. S., Fil'aini, R., Fahrani, A. C., Cahyani, D., Sinaga, A. O. Y. (2019). Physical changes of andaliman (Zanthoxylum Acanthopodium Dc.) in packaging during lowtemperature storage. Agrointek,13(6), 1-7.
Oktavianty, N. U., \& Wildian, W. (2016). Rancang bangun alat ukur dan indikator kadar air gabah siap giling berbasis mikrokontroler dengan sensor fotodioda. Jurnal Fisika Unand, 5, 94-100.

Palacios, H., Villamarín, D., Velásquez, J., \& Vásquez, W. (2019). Comparison of methodologies for determination total humidity in hard corn (Zea mays L.). In IOP Conference Series: Earth and Environmental Science (IOP Publishing), pp. 012070. Hanif, S., Sultan, M., Miyazaki, T., and Koyama, S. (2018). Steady-state Investigation of Desiccant Drying System for Agricultural Applications. Evergreen, 5, 33-42.

Sauer, D., \& Tuite, J. (1987). Conditions that affect growth of Aspergillus flavus and production of aflatoxin in stored maize. In US Universities-CIMMYT Maize Aflatoxin Workshop, El Batan, Mexico (Mexico), 7-11 Apr 1987 (Cimmyt).

Savero, E., Soelistianto, F. A., \& Hudiono, H. (2018). Uji kualitas kadar air benih jagung dengan metode kapasitif berbasis web. Jurnal Jartel: Jurnal Jaringan Telekomunikasi, 7 (68), $1-9$.

Skoufogianni, E., Solomou, A., Charvalas, G., Danalatos, N. (2019). Maize as Energy Crop (IntechOpen).

Thiex, N., \& Richardson, C. (2004). Challenges in measuring moisture content of feeds. Journal of animal science, 81, 3255-3266.

Thompson, T., Peart, M., G H Foster, R. (1968). Mathematical Simulation of Corn Drying- A New Model. Transactions of the $A S A E, 11,582-0586$.

Widyasanti, A., Marpaung, D. S., \&Nurjanah, S. (2017). Aktivitas anti jamur ekstrak the putih (Camelia sinensis) terhadapjamur candida albicans. Jurnal Teknotan, 10:1-9.

Zhang, H.-L, Ma, Q., Fan, L., Zhao, P., Jianxu, W., Zhang, X. D., Zhu, D., Huang, L., Zhao, D., Wang, Z-y. (2016). Nondestructive In Situ Measurement Method for Kernel Moisture Content in Corn Ear, Sensors 16.

Zhang, J., Mittal, G.S. (2013). Prediction of equilibrium moisture content of various foods using a neural network. International Journal of Food Properties, 16, 1211-1221. 